\title{
SEROLOGICAL AND MOLECULAR SURVEY OF SERIOUS INTRACELLULAR COCCIDIA IN RED FOXES IN EASTERN SLOVAKIA
}

\author{
Reiterová, K., Špilovská, S., Čobádiová, A. \\ Institute of Parasitology of the Slovak Academy of Science \\ 04001 Košice, Hlinkova 3 \\ The Slovak Republic \\ reiter@saske.sk
}

\section{ABSTRACT}

We tested the sera or meat juices of 215 red foxes (Vulpes vulpes), collected during 2009-2014 at different localities of Eastern Slovakia for the presence of antiToxoplasma and anti-Neospora antibodies. We also examined the brains or muscle tissues and uncoagulated blood samples for the presence of both parasite's DNA. The mean seropositivity to $T$. gondii was $72.6 \%$ (95\% Confidence Interval CI 66.1-78.4) and to $N$. caninum $33.9 \%$ (95\% CI 27.7-40.7). We observed higher Toxoplasmaseropositivity in adults $(71.1 \%)$ than in juveniles $(60.0 \%)$. Neospora-seropositivity was almost the same in both age groups about of $\mathbf{3 0} \%$. In general, we observed less frequently the DNA of parasites, T. gondii $(14.5 \%)$ and N. caninum $(20.3 \%)$ in the tissue samples and uncoagulated blood samples. Coccidioses are considerably common in red foxes and circulate in locations of Eastern Slovakia. The high infection rate in foxes is probably due to their infected prey. On the other hand, the contamination of the environment with oocysts and their subsequent transfer to other farm and wild animals is also possible.
Key words: antibodies, DNA; ELISA; Neospora caninum; PCR; red foxes; Toxoplasma gondii; Slovakia

\section{INTRODUCTION}

The population density of red foxes (Vulpes vulpes) after successful oral anti-rabies vaccination has significantly increased throughout Europe. Their expansion to nearby human settlements (the phenomenon of urbanization) has also been going on [6]. Foxes participate in the spread of several parasitic diseases, such as toxoplasmosis and neosporosis.

Toxoplasma gondii and Neospora caninum are two closely related protozoan parasites with worldwide occurrence, having an indirect life cycle with cats and other wild feline carnivores as definitive hosts for T. gondii; and dogs and other canine carnivores for $N$. caninum. Oocysts are excreted in the faeces of the definitive host to the environment where they mature and can cause infection in some host species, including both domestic and wild animals [4], [7]. 
Toxoplasmosis is a widespread zoonotic disease, causing serious medical problems especially in pregnant women and immunosuppressed patients [16]. Humans become infected due to the consumption of inadequately cooked meat containing tissue cysts or by ingestion of sporulated oocysts, and also by transplacental transmission [4].

Neosporosis causes repeated abortions in cattle and other farm ruminants and has a negative economic impact on their breeding [3]. Both parasitoses circulate in both sylvatic and domestic cycles. The infections can be transmitted to stables due to poor zoohygiene by rodents or by contact with free living animals.

The aim of this study was to evaluate the occurrence of anti-Toxoplasma and -Neospora antibodies in red foxes from different locations of Eastern Slovakia and to associate the seroprevalence with their DNA evidence.

\section{MATERIALS AND METHODS}

Within the period of 2009 to 2014, we collected blood, brain and muscle tissue samples of red foxes from different localities of Eastern Slovakia; in particular from localities of agricultural lands and farms. The blood and tissue samples were obtained from the Department of Pathology of the State Veterinary and Food Institute in Košice from foxes which had been trapped or shot for rabies control and also from individual hunting. Sera were prepared from coagulated blood by centrifugation at $600 \mathrm{~g}$ for $10 \mathrm{~min}$. In case when blood samples were absent, meat juices were prepared by freeze-thawing from muscle samples for serological testing. Tissue and uncoagulated blood samples were removed for molecular analysis. All samples were kept at $-20^{\circ} \mathrm{C}$ up to further analyses.

The circulating anti-Toxoplasma antibodies were tested by the multi-species indirect ELISA (ID-Vet, Montpellier, France) using the manufacturer's protocol. We examined a total of 150 serum samples and 65 meat juices. The sera were diluted at 1:10 and meat juices 1:2. Protein G peroxidase labelled conjugate, which recognizes mammalian IgG antibodies and a TMB (3,3',5,5' -Tetramethylbenzidine) substrate, were used. The absorbance (OD) was measured at $450 \mathrm{~nm}$ by a spectrophotometer (Thermolabsystem, Opsys MR, U.S.A.). The results were calculated as $\mathrm{S} / \mathrm{P} \%$ index according to the formula: S/P\% $=($ ODsample $-\mathrm{ODNC} /$ ODPC-ODNC) - 100. The samples with $\mathrm{S} / \mathrm{P} \% \leq 40 \%$ were negative; between $40 \%$ and $50 \%$ doubtful and with $\mathrm{S} / \mathrm{P} \% \geq 50 \%$, were categorized as positive.

For the detection of the anti-Neospora antibodies, a competitive ELISA (VMRD, Inc., Pullman, USA) test was used according to the manufacturer's instructions. Non-diluted serum samples or meat juices were added to the wells of the antigen-coated plates. The absorbance was measured at $630 \mathrm{~nm}$. A test was considered valid, if the mean of the Positive Controls formed $\geq 30 \%$ inhibition of the reaction, $\% \mathrm{I}=100-(\mathrm{ODsample} / \mathrm{ODNC} \times 100)$. The results were negative when the tested sample produced $<30 \%$ inhibition and positive if they produced $\geq 30 \%$ inhibition.

We isolated DNA from the brain and skeletal muscle tissues by NucleoSpin ${ }^{\oplus}$ Tissue kit (Macherey-Nagel, Germany) with a previous overnight digestion with proteinase $\mathrm{K}$ (Promega, Madison, WI) at $56^{\circ} \mathrm{C}$. Isolation from non-coagulated blood samples was performed by NucleoSpin ${ }^{\circledR}$ Blood kit (Macherey-Nagel, Germany), according to the manufacturer's instructions. The isolates were stored at $-20^{\circ} \mathrm{C}$ until the analysis.

The amplification of the TGR1E gene of $191 \mathrm{bp}$ in size repeated itself in the T. gondii genome 30-35 times was made using two primers: TGR1E-1 and TIGRIE-25 [13]. DNA-free molecular water was used as the negative and T. gondii RH-strain (NRL for Toxoplasmosis, Prague, Czech Republic) as the positive control. The PCR products were analysed in $1.5 \%$ agarose gel with GelRed dye and evaluated under UV light.

The detection of the Nc5 gene of N. caninum was performed with specific primer pairs: Np6 and Np21 [19]. The amplifications were approved in a gradient thermocycler (Bioer, China). The first Slovak N. caninum isolate [14] was used as positive and DNA-free water as negative control. The PCR products were analysed in $1 \%$ agarose gel and evaluated under UV lamp using a digital camera (Panasonic AC 40).

The results of the serological investigations were evaluated statistically by the Fisher exact test (GraphPad Software). The prevalence and exact confidence intervals at $95 \%$ level were computed. The significance of the differences were evaluated using STATISTICA 6 Base (StatSoft, Inc., 2001). 


\section{RESULTS}

In 215 foxes from the localities of eight eastern Slovak districts the mean level of anti-Toxoplasma and anti-Neospora antibodies were detected in $72.6 \%$ (95\% Confidence Interval CI 66.1-78.4) and 33.5\% (95\% CI 27.2-40.2) of the samples, respectively. The higher Toxoplasma-seropositivity was detected in adults (71.1\%; $95 \%$ CI 62.4-78.8) compared to the juveniles (60.0\%; $95 \%$ CI $36.1-80.9)$. The Neospora-seropositivity was almost the same in the adults and the juvenile categories, or only those of unknown age.

Toxoplasma-infection was present on a similar level in both genders ( $72.3 \%$ in males and $69.7 \%$ in females). However, males were more frequently infected with $N$. caninum $(39.8 \%)$ compared to the females $(23.7 \%)$. Toxoplasmosis was detected in all districts at a high level, varying between $50.0 \%$ and $78.4 \%$. The level of specific antibodies was high and values of S/P\% indexes fluctuated from $96.5 \%$ to $260.3 \%$. Neosporosis was present in seven districts with fluctuation from $25.9 \%$ to $46.3 \%$. The percentage of inhibition of cELISA varied between $33.0 \%$ and $105.5 \%$. The serological follow-up of toxoplasmosis revealed a slight decrease in individual years from $80.6-54.5 \%$. On the other hand, the yearly occurrence of neosporosis was most variable with the significantly lowest seropositivity in 2014 (4.5\%; P =0.0009) (Table 1). The occurrence and the linear trend of Toxoplasma- and Neospora-seropositivity in red foxes of both examined coccidiosis is shown in Figure 1.

The molecular detection revealed a significantly lower rate of T. gondii (14.5\%) and N. caninum (20.3\%) DNA evi-

Table 1. The occurrence of specific"antibodies in red foxes according to the year, age, gender and the hunting locality

\begin{tabular}{|c|c|c|c|c|c|c|c|c|c|c|c|c|}
\hline \multirow{3}{*}{ Years } & \multirow{2}{*}{\multicolumn{2}{|c|}{$\begin{array}{c}2009 \\
N / n\end{array}$}} & \multirow{2}{*}{\multicolumn{2}{|c|}{$\begin{array}{l}2010 \\
N / n\end{array}$}} & \multirow{2}{*}{\multicolumn{2}{|c|}{$\begin{array}{c}2012 \\
N / n\end{array}$}} & \multirow{2}{*}{\multicolumn{2}{|c|}{$\begin{array}{l}2014 \\
N / n\end{array}$}} & \multicolumn{2}{|c|}{ Total } & \multicolumn{2}{|c|}{ Total } \\
\hline & & & & & & & & & \multirow{2}{*}{\multicolumn{2}{|c|}{$\begin{array}{ll}\mathrm{N} / \mathrm{n} / \% & 95 \% \mathrm{Cl} \\
\text { Toxoplasma gondii }\end{array}$}} & \multirow{2}{*}{\multicolumn{2}{|c|}{$\begin{array}{l}\mathrm{N} / \mathrm{n} / \% \quad 95 \% \mathrm{Cl} \\
\text { Neospora caninum }\end{array}$}} \\
\hline & T. $g$. & N.c. & T. $g$. & N.c. & T. $g$. & N.c. & T.g. & N.c. & & & & \\
\hline \multicolumn{13}{|c|}{ Age category } \\
\hline Juvenile & $2 / 1$ & $2 / 0$ & - & - & $17 / 11$ & $17 / 6$ & $1 / 0$ & $1 / 0$ & $20 / 12 / 60.0$ & $36.1-80.9$ & $20 / 6 / 30.0$ & $11.9-54.3$ \\
\hline Adult & $28 / 23$ & $28 / 13$ & - & - & $58 / 44$ & $58 / 24$ & $42 / 24$ & $42 / 2$ & 128/91/71.1 & $62.4-78.8$ & $128 / 39 / 30.5$ & $22.7-39.2$ \\
\hline Unknown & $6 / 5$ & $6 / 0$ & $58 / 46$ & $58 / 26$ & $2 / 2$ & $2 / 2$ & $1 / 0$ & $1 / 0$ & 67/53/79.1 & $67.4-88.1$ & $67 / 28 / 41.8$ & $29.8-54.5$ \\
\hline \multicolumn{13}{|c|}{ Gender } \\
\hline Male & $17 / 15$ & $17 / 6$ & $3 / 3$ & $3 / 1$ & $40 / 32$ & $40 / 21$ & $23 / 10$ & $23 / 1$ & $83 / 60 / 72.3$ & $61.4-81.6$ & $83 / 29 / 39.8$ & $29.2-51.5$ \\
\hline Female & $19 / 14$ & $19 / 7$ & $1 / 1$ & $1 / 0$ & $36 / 24$ & $36 / 10$ & $20 / 14$ & $20 / 1$ & $76 / 53 / 69.7$ & $58.1-79.6$ & $76 / 18 / 23.7$ & $14.7-34.8$ \\
\hline Unknown & - & - & $54 / 42$ & $54 / 25$ & $1 / 1$ & $1 / 1$ & $1 / 0$ & $1 / 0$ & $56 / 43 / 76.8$ & $63.6-87.0$ & $56 / 26 / 46.4$ & $32.9-60.2$ \\
\hline \multicolumn{13}{|c|}{ Districts } \\
\hline Gelnica & - & - & - & - & $9 / 7$ & $9 / 4$ & $4 / 2$ & $4 / 0$ & $13 / 9 / 69.2$ & $38.6-90.9$ & $13 / 4 / 30.8$ & $9.1-61.4$ \\
\hline Košice & $31 / 25$ & $31 / 11$ & $19 / 17$ & $19 / 8$ & $9 / 8$ & $9 / 5$ & $15 / 8$ & $15 / 1$ & $74 / 58 / 78.4$ & $67.3-87.1$ & $74 / 24 / 32.4$ & $22.0-44.3$ \\
\hline Michalovce & - & - & $8 / 7$ & $8 / 3$ & $24 / 18$ & $24 / 10$ & $9 / 6$ & $9 / 1$ & $41 / 31 / 75.6$ & $59.7-87.6$ & $41 / 14 / 34.1$ & $20.1-50.6$ \\
\hline Rožňava & - & - & $2 / 1$ & $2 / 1$ & $4 / 2$ & $4 / 1$ & - & - & $6 / 3 / 50.0$ & $11.8-88.2$ & $6 / 2 / 33.3$ & $4.3-77.7$ \\
\hline S.N. Ves & - & - & $13 / 11$ & $13 / 5$ & $7 / 5$ & $7 / 2$ & $7 / 4$ & $7 / 0$ & 27/20/74.1 & $53.7-88.9$ & $27 / 7 / 25.9$ & $11.1-46.3$ \\
\hline Sobrance & $1 / 1$ & $1 / 0$ & - & - & $3 / 3$ & $3 / 0$ & $3 / 1$ & $3 / 0$ & $7 / 5 / 71.4$ & $29.0-96.3$ & $7 / 0 / 0$ & $0.0-34.8$ \\
\hline Trebišov & - & - & $16 / 10$ & $16 / 9$ & $21 / 14$ & $21 / 10$ & $4 / 2$ & $4 / 0$ & $41 / 26 / 63.4$ & $46.9-77.9$ & $41 / 19 / 46.3$ & $30.7-62.6$ \\
\hline Vranov & $4 / 3$ & $4 / 2$ & - & - & - & - & $2 / 1$ & $2 / 0$ & $6 / 4 / 66.7$ & $22.3-95.7$ & $6 / 2 / 33.3$ & $4.3-77.7$ \\
\hline TotalN/n & $36 / 29$ & $36 / 13$ & $58 / 46$ & $58 / 26$ & $77 / 57$ & $77 / 32$ & $44 / 24$ & $44 / 2$ & $215 / 156 / 72.6$ & $66.1-78.4$ & $215 / 73 / 33.9$ & $27.7-40.7$ \\
\hline [\%] & 80.6 & 36.1 & 79.3 & 44.8 & 74.0 & 41.6 & 54.5 & 4.5 & & & & \\
\hline
\end{tabular}

T. g. - Toxoplasmagondii; N. c. - Neosporacaninum; N - number of animalsexamined $\mathrm{n}$ - number of positive animals; \% - seropositivity 
Table 2.Molecular evidence of Toxoplasma gondii and Neospora caninum in red foxes bythe years and examined sample types

\begin{tabular}{|c|c|c|c|c|c|c|c|c|c|c|c|}
\hline \multirow{2}{*}{$\begin{array}{l}\text { Years/ } \\
\text { T.g./N.c. }\end{array}$} & \multicolumn{3}{|c|}{2009} & \multicolumn{3}{|c|}{2010} & \multicolumn{2}{|c|}{2012} & \multicolumn{2}{|c|}{2014} & \multirow{2}{*}{$\begin{array}{c}\text { Total } \\
\text { N/n/\% }\end{array}$} \\
\hline & $A$ & B & C & $A$ & B & C & $A$ & B & B & C & \\
\hline $\begin{array}{l}\text { Examined } \\
{[\mathrm{N}]}\end{array}$ & - & 20 & 20 & 4 & 38 & - & - & 47 & 40 & 4 & \\
\hline $\begin{array}{l}\text { Positive } \\
\text { [n] }\end{array}$ & - & 9 & 1 & 0 & 0 & - & - & 7 & 6 & 2 & \\
\hline $\begin{array}{l}\text { Prevalence } \\
{[\%]}\end{array}$ & - & 4.5 & 0.5 & 0 & 0 & - & - & 14.9 & 15.0 & 50.0 & \\
\hline $\begin{array}{l}\text { Total T.g. } \\
\text { N/n/\% }\end{array}$ & \multicolumn{3}{|c|}{$40 / 10 / 25.0$} & \multicolumn{3}{|c|}{$42 / 0 / 0.0$} & \multicolumn{2}{|c|}{$47 / 7 / 14.9$} & \multicolumn{2}{|c|}{$44 / 8 / 18.2$} & $173 / 25 / 14.5$ \\
\hline $\begin{array}{l}\text { Examined } \\
{[\mathrm{N}]}\end{array}$ & 1 & 24 & 20 & 9 & 30 & 33 & 13 & 23 & 40 & 4 & \\
\hline $\begin{array}{l}\text { Positive } \\
\text { [n] }\end{array}$ & 1 & 11 & 0 & 5 & 12 & 3 & 3 & 4 & 1 & 0 & \\
\hline $\begin{array}{l}\text { Prevalence } \\
\text { [\%] }\end{array}$ & 100 & 45.8 & 0 & 55.6 & 40.0 & 9.1 & 23.1 & 17.4 & 2.5 & 0 & \\
\hline $\begin{array}{l}\text { Total N.c. } \\
\text { N/n/\% }\end{array}$ & & $45 / 12 / 26.7$ & & & $72 / 20 / 27.8$ & & & & & & $197 / 40 / 20.3$ \\
\hline
\end{tabular}

T. g. - T. gondii; N. c. — N. caninum; A — DNA isolated from blood; B — DNA isolated from brain; C — DNA isolated from muscle tissue

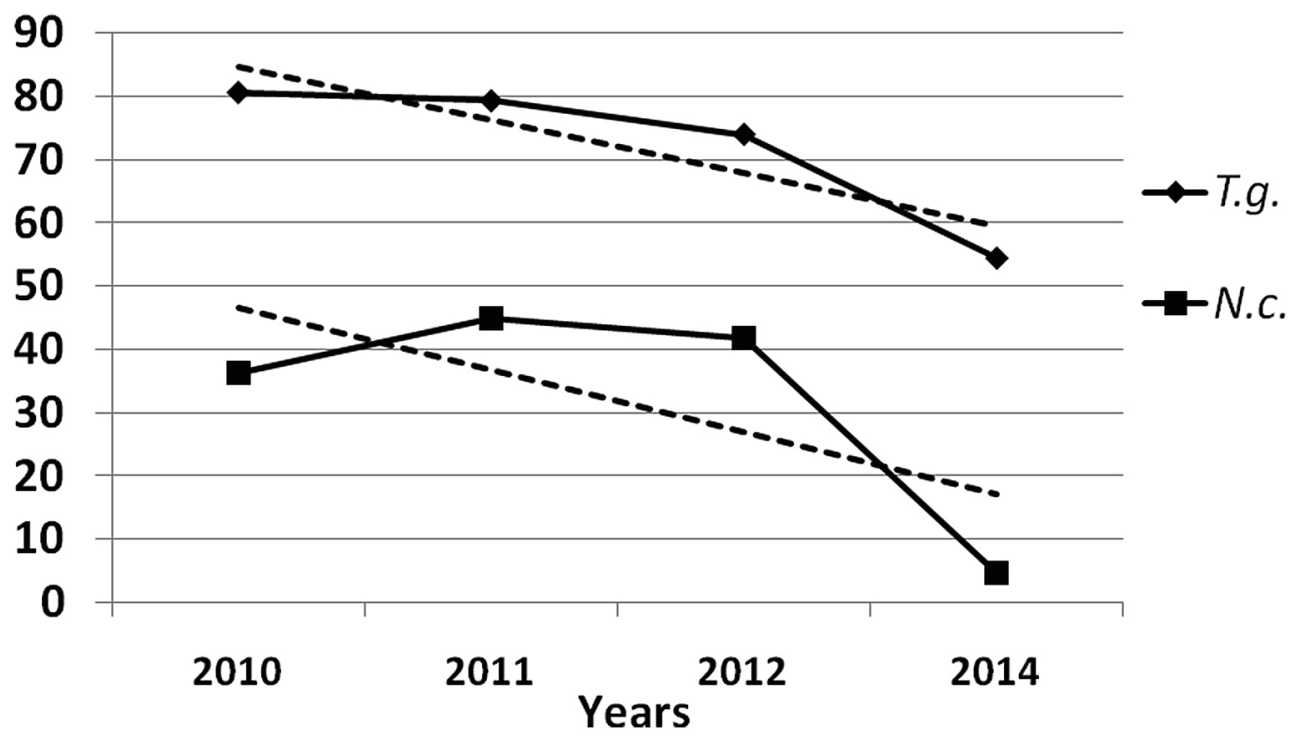

Fig. 1. The occurrence and linear trend of Toxoplasma- and Neospora-seropositivity in red foxes from different locations of Eastern Slovakia 
dence in the tissues and blood samples (Table 2) when compared with the serological evidence. The presence of T. gondii was confirmed in $15.2 \%$ of the brain tissue samples and $12.5 \%$ of the muscle samples. The genomic DNA of N. caninum was confirmed in $23.9 \%$ of the brain samples, $39.1 \%$ in the uncoagulated blood and only $5.3 \%$ of the muscle samples (Table 2). Coinfection was detected in three samples, which were simultaneously PCR positive for both parasites.

\section{DISCUSSION}

During the past three decades, the rapidly increasing population density of red foxes has had a significant effect on the prevalence of infections, including coccidioses. This fact has resulted in an increased risk of contact with oocysts due to the greater amount of animals in a small area [10]. The high incidence of toxoplasmosis, and likewise neosporosis, in wildlife is explained by the high abundance of the causative agents in the diets of the foxes. An important prey for foxes represents rodents. On the other hand, the carcasses of the infected foxes can serve as the source of infection for the definitive hosts by contaminating the environment with oocysts. This phenomenon corresponds to our overall detection rate up to $72.6 \%$ Toxoplasma-seroprevalence in foxes. The occurrences of toxoplasmosis in red foxes from localities of Eastern Slovakia are higher in comparison to other Western European countries where seropositivity vary from $20 \%$ to $47 \%$ [8, [11], [17], [18] In accordance with our high seropositivity rate, also in neighbouring Hungary, high (68\%) seroprevalence has been detected in red foxes [12]. Similarly, in Central and Eastern Germany, $74.5 \%$ and $84.7 \%$ of the foxes had antibodies to T. gondii [9]. The age and gender of foxes did not influence the seropositivity significantly; however, older animals were infected more frequently than juveniles. We could deduce that the infection is transmitted mainly via infected prey or sporulated oocysts and only sporadically by transplacental transmission.

Despite the high seropositivity rate, the molecular evidence of T. gondii was one fifth lower. Similarly, in foxes from Germany $13.4 \%$ were PCR-positive [9]. By multiplex real-time PCR, T. gondii was detected in $18.8 \%$ of the brain samples in Belgian red foxes [2]. In a recent study $6 \%$ of T. gondii DNA was confirmed in the fox brain tissues from Romania [15].
Concerning the neosporosis in wild carnivores, their natural prey are frequently the source of infections [5]. The presence and distribution of neosporosis in wildlife may represent a high infection risk for livestock, especially during the grazing season. Our results revealed $24.6 \%$ mean Neospora-seropositivity, which is higher than the prevalence in other countries of Western Europe, where the seropositivity varied between $11 \%$ and $17 \%$ [1], [18]. In Hungary, only $1.5 \%$ Neospora-seroprevalence of red foxes was estimated [12]. The absence of significant age-related differences of Neospora-seropositivity may suggest that infections could be transmitted mainly via the transplacental way, as in cattle.

\section{CONCLUSIONS}

The high occurrence of anti-Toxoplasma gondii (72.6\%) and anti-Neospora caninum (33.9\%) antibodies in red foxes from different locations of Eastern Slovakia suggests their important role in the maintenance of sylvatic circulation of both coccidian parasites as a reservoir host. The serological follow-up revealed a reasonable decreasing trend during the examined period. Despite the high serological evidence, DNA of both parasites was significantly less frequently confirmed from tissue and blood samples. A simultaneously positive molecular finding for both coccidia was detected only in three cases. In order to disclose the actual role of red foxes in the epidemiology of toxoplasmosis and neosporosis, more extensive study is required in widespread ranges of natural ecosystems.

\section{ACKNOWLEDGEMENTS}

The authors are grateful for the biological material provided by Peter Smrčo, DVM, PhD., University of Veterinary Medicine and Pharmacy in Košice, and to Martin Oravec, DVM, SVFI in Košice. The study was supported by the Slovak Scientific Grant Agency VEGA grants 2/0068/15 and the Project "INFEKTZOON - Centre of Excellence For Animal Infections and Zoonoses (ITMS-26220120002)” (0.4). 


\section{REFERENCES}

1. Almería, S., Ferrer, D., Pabo, M., Castella, J., Manas, S., 2002: Red foxes (Vulpes vulpes) are a natural intermediate host of Neospora caninum. Vet. Parasitol., 107, 287-294.

2. De Craeye, S., Speybroeck, N., Ajzenberg, D., Darde, M. L., Collinet, F., Tavernier, P., et al., 2011: Toxoplasma gondii and Neospora caninum in wildlife: Common parasites in Belgian foxes and Cervidae? Vet. Parasitol., 178, 64-69.

3. Dubey, J. P., 2003: Review of Neospora caninum and neosporosis in animals. Korean J. Parasitol., 41, 1-16.

4. Dubey, J. P., Beattie, C.P., 1988: Toxoplasmosis of Animals and Man. CRC Press, Boca Raton, 220 pp.

5. Ferroglio, E., Pasino, M., Romano, A., Grande, D., Pregel, P., Trisciuoglio, A., 2007: Evidence of Neospora caninum DNA in wild rodents. Vet. Parasitol., 148, 346-349.

6. Gloor, S., Bontadina, F., Hegglin, D., Deplazes, P., Breitenmoser, U., 2001: The rise of urban fox populations in Switzerland. Mammal. Biol., 66, 155-164.

7. Gondim, L.F., McAllister, M.M., Mateus-Pinilla, N.E., Pitt, W.C., Mech, L.D., Nelson, M.E., 2004: Transmission of Neospora caninum between wild and domestic animals. J. Parasitol., 90, 1361-1365.

8. Hamilton, C.M., Gray, R., Wright, S.E., Gangadharan, B., Laurenson, K., Innes, E. A., 2005: Prevalence of antibodies to Toxoplasma gondii and Neospora caninum in red foxes (Vulpes vulpes) from around the UK. Vet. Parasitol., 130, 169-173.

9. Herrmann, D. C., Maksimov, P., Maksimov, A., Sutor, A., Schwarz, S., Jaschke, W., et al., 2012: Toxoplasma gondii in foxes and rodents from the German Federal States of Brandenburg and Saxony-Anhalt: Seroprevalence and genotypes. Vet. Parasitol., 185, 78-85.

10. Hollings, T., Jones, M., Mooney, N., McCallum, H., 2013: Wildlife disease ecology in changing landscapes: Mesopredator release and toxoplasmosis. Int. J. Parasitol. Parasites Wildl., 2, 110-118.
11. Jakubek, E. B., Brojer, C., Regnersen, C., Uggla, A., Schares, G., Bjorkman, C., 2001: Seroprevalences of Toxoplasma gondii and Neospora caninum in Swedish red foxes (Vulpes vulpes). Vet. Parasitol., 102, 167-172.

12. Jakubek, E. B., Farkas, R., Palfi, V., Mattsson, J. G., 2007: Prevalence of antibodies against Toxoplasma gondii and Neospora caninum in Hungarian red foxes (Vulpes vulpes). Vet. Parasitol., 144, 39-44.

13. Lamoril, J., Molina, M.J., Gouvello, A., Garin, J.Y., Deybach, C. J., 1996: Detection by PCR of Toxoplasma gondii in blood in the diagnosis of cerebral toxoplasmosis in patients with AIDS. J. Clin. Pathol., 49, 89-92.

14. Reiterová, K., Špilovská, S., Čobádiová, A., Mucha, R., 2011: First in vitro isolation of Neospora caninum from a naturally infected adult dairy cow in Slovakia. Acta Parasitol., 56, 111-115.

15. Suteu, O., Mihalca, A. D., Pastiu, A.I., Györke, A., Matei, I. A., Ionica, A. et al., 2014: Red foxes (Vulpes vulpes) in Romania are Carriers of Toxoplasma gondii but not Neospora caninum. J. Wildl. Dis., 50, 713-716.

16. Tenter, A.M., Heckeroth, A.R., Weiss, L.M., 2000: Toxoplasma gondii: from animals to humans. Int. J. Parasitol., 30, 1217-1258.

17. Wanha, K., Edelhofer, R., Gabler-Eduardo, C., Prosl, H., 2005: Prevalence of antibodies against Neospora caninum and Toxoplasma gondii in dogs and foxes in Austria. Vet. Parasitol., 128,189-193.

18. Wolfe, A., Hogan, S., Maguire, D., Fitzpatrick, C., Vaughan, L., Wall, D., et al., 2001: Red foxes (Vulpes vulpes) in Ireland as hosts for parasites of potential zoonotic and veterinary significance. Vet. Rec., 149, 759-763.

19. Yamage, M., Flechtner, O., Gottstein, B., 1996: Neospora caninum: Specific oligonucleotide primers for the detection of brain "cyst" DNA of experimentally infected nude mice by the polymerase chain reaction (PCR). J. Parasitol., 82, 272-279.

Received April 28, 2016 